\title{
The state of HRM in the Middle East: Challenges and future research agenda
}

\author{
Pawan Budhwar $^{1} \cdot$ Vijay Pereira $^{2,3}$ (D) Kamel Mellahi $^{4} \cdot$ Sanjay Kumar Singh $^{5}$
}

Published online: 1 July 2018

(C) The Author(s) 2018, corrected publication July/2018

\begin{abstract}
Based on a robust structured literature analysis, this paper highlights the key developments in the field of human resource management (HRM) in the Middle East. Utilizing the institutional perspective, the analysis contributes to the literature on HRM in the Middle East by focusing on four key themes. First, it highlights the topical need to analyze the context-specific nature of HRM in the region. Second, via the adoption of a systematic review, it highlights state of development in HRM in the research analysis set-up. Third, the analysis also helps to reveal the challenges facing the HRM function in the Middle East. Fourth, it presents an agenda for future research in the form of research directions. While doing the above, it revisits the notions of "universalistic" and "best practice" HRM (convergence) versus "best-fit" or context distinctive (divergence) and also alternate models/diffusion of HRM (crossvergence) in the Middle Eastern context. The analysis, based on the framework of cross-national HRM comparisons, helps to make both theoretical and practical implications.
\end{abstract}

Keywords Middle East $\cdot$ HRM $\cdot$ Determinants $\cdot$ HR challenges $\cdot$ Future research

The developments in the field of human resource management (HRM), especially in the developed parts of the world, are now well documented (see Jackson, Schuler, \& Jiang, 2014 for a detailed review of the field). Also, increasing attempts are being made to highlight the state of HRM field in emerging markets (e.g., Horwitz \& Budhwar, 2015), under researched countries (e.g., see Nguyen, Teo, \& Ho, 2018for a review on

Vijay Pereira

vijay.pereira@port.ac.uk

1 Aston Business School, Birmingham, UK

2 Wollongong Business School, Dubai, UAE

3 University of Portsmouth, Richmond Building, Portland St., Portsmouth PO1 3DE, UK

4 Warwick Business School, Coventry, UK

5 Abu Dhabi University, Abu Dhabi, UAE 
HRM in Vietnam) and other parts of the world (e.g., Chen, Chuang, \& Chen, 2018). Over the past couple of decades, we can see a steady stream of research emerging related to HR issues in the Middle East. A literature review of last three years highlights a surge in HR-related research for this context (see Table 6). It also reveals a fragmented picture of the scene and the clear absence of a comprehensive review which can not only help to report the key developments in the field, but also guide future research. An attempt is made in this paper to address such gaps.

There are a variety of reasons which support the topical need for this analysis. An overarching one is the strong scarcity of reliable literature and its systematic contextual analysis on the topic of HRM and the growing interest of both researchers and practitioners in the region of the Middle East (see Afiouni, Ruël, \& Schuler, 2014; Budhwar \& Mellahi, 2016). Also, the Middle Eastern context is a unique and interesting ground for studying and researching international HRM (IHRM) because of the unique nature of the workforce in this region, who are predominantly expatriates from different parts of the world.

A number of related reasons include the developments in the fields of HRM and IHRM where the present debate is linked to the contribution of the HR function towards organizational performance (e.g., Chow, Teo, \& Chew, 2013; Gerrard \& Lockett, 2018; Kim \& Sung-Choon, 2013; Ma, Long, Zhang, Zhang, \& Lam, 2017) (to what extent this is valid for firms operating in the Middle East?) and the convergence-divergence thesis (to what extent HRM in the Middle East is converging-diverging with other parts of the world) respectively; growing interest of businesses, researchers and policy makers in the region as it continues to economically grow amidst of socio-political and security-related developments, some of which are still unfolding; there are regular calls for such analysis for the under-researched parts of the world (e.g., Gao, Zuzul, Jones, \& Khanna, 2017); and the influence of the unique socio-cultural and the rapidly changing institutional set-up of the Middle East (e.g., the nationalization programs being pursued dealing with recruitment and development of citizens to increase their employability, thereby reducing the country's dependence on an expatriate workforce) is not yet adequately researched. Moreover, in the absence of robust information, it is not clear about the nature and intensity of forces determining the approaches adopted to managing human resources and their suitability for firms operating there; and to highlight the context-specific nature of the HRM function and the prevalence of dominant indigenous HRM approaches for the region (Afiouni et al., 2014; Budhwar \& Mellahi, 2016). All such factors create huge research avenues for further theory development and developing context specific best HRM practices.

Accordingly, the main aims of this paper are twofold: first, to highlight the current state of HRM development in the Middle East, and second, to set an agenda for future HRM research for the region. Our analysis is aimed to respond to regular calls made by scholars in the field (e.g., Budhwar, Varma, \& Patel, 2016; Cooke, 2018) for systematic reviews of developments in the field of HRM for under researched contexts. We utilize the institutional theory (DiMaggio \& Powell, 1983 ) to guide our analysis. The institutional theory helps to reveal how contextual forces (such as cultural, legal, economic, political, among others) influence change in the nature of managerial practices (including HRM) according to change in the institutional environment of a given set-up (in this case the region of the Middle East) (for details see DiMaggio \& Powell, 1983; Scott, 2008). 
By doing so, our paper is expected to make useful theoretical implications. It is also expected to guide future research investigations and help practitioners to develop context-relevant HRM policies and practices. The remaining paper is structured as following. Initially, we present a brief about the Middle Eastern context, emphasizing the changes in its business environment linking it with the institutional theory perspective. This is followed by a description of our approach to literature analysis. Next, we present an overview on the developments in HRM in the Middle East. This is followed by themes identified for future research. Finally, we discuss the theoretical and practical implications of our analysis.

\section{The Middle East context-An institutional perspective}

Broadly speaking, the term Middle East defines a cultural area, which does not have precise borders. A variety of terminologies have been used to denote the region. These vary from "Middle East," "Near East," "Middle East-North Africa (MENA)," "Southwest Asia," "Greater Middle East," "Levant," "Arabian Peninsula" or the "Arab World" in a very general sense, terms used by both academics and policy makers (see Budhwar \& Mellahi, 2016). For our analysis, we use the wider version of the Middle East which includes not only the Gulf Cooperation Council (GCC) states, but also MENA countries. The region is the birthplace of three main religions-Islam (followed by approximately $95 \%$ of the total population out of which $85 \%$ are Sunnis and remaining Shias), Judaism and Christianity. The population of the Middle East is over 380 million. The region also hosts around $65 \%$ of the world's known oil reserves.

From an institutional theory perspective and in order to have a good understanding of the Middle Eastern context, we consider three components of its institutional contexts - regulatory (covering topics like the governance structures, legal framework), cognitive (focusing on topics like shared social knowledge) and normative (such as culture depicted via norms dictating life style, commonly held assumptions and beliefs) (for details see Scott, 2008; Powell \& DiMaggio, 2012). New institutionalism in particular, highlights the isomorphism of organizational policies and practices in a given environment and is based on three mechanisms of coercive (e.g., political influence of key institutions, such as the government), mimetic (emphasizing on the forces in the external environment creating uncertainties and influencing performance) and normative (e.g., adopting acceptable standards and routines). These mechanisms of isomorphism tend to create homogeneity of HRM development in a given context (for details see Scott, 2004, 2008; Greenwood \& Hinings, 1996). Indeed, the impact of these mechanisms on HRM is context specific and results in heterogeneity of HRM development for specific context(s). A framework based on such components is known to facilitate the conduct our proposed context-specific HRM analysis; a call regularly made by scholars (e.g., Budhwar \& Debrah, 2009; Klien \& Delery, 2012; Meyer, 2006; Nguyen et al., 2018).

In this regard, scholars (e.g., Afiouni et al., 2014; Budhwar \& Mellahi, 2006, 2016) have initiated a move to highlight the indigenous management constructs and models valid and suitable for the Middle East region and their impact on management of human resources (e.g., Klien \& Delery, 2012; Smith et al., 2012; Ta'Amnha, Sayce, \& Tregaskis, 2016). Nevertheless, there is still a scarcity of research focusing on the 
nature of dominant HRM system(s), forces determining the same, challenges faced by the HR function and the future of HRM in the Middle East. Addressing the above presented aims will help address such identified gaps.

\section{Methodology and key results}

As indicated above, the HRM literature in the Middle East is widely dispersed which directed us to adopt a structured review (Tranfield, Denyer, \& Smart, 2003) for the search and selection of published literature based on the parameters of relevance, quality and recentness. In the first instance, and primarily focusing on the "relevance" parameter and to get an overview of the scene regarding the number of articles published, for which region/country in the Middle East they have been published and the kind of themes they represent, we used ProQuest for searching articles and studies that relate and focus on key HRM themes and terms relevant for our analysis. For this, each paper that is included for this analysis is peer-reviewed and available in full-text format. The search was conducted in January and February of 2018 and the details and steps of our search strategy is as follows. In general, we conducted a number of Boolean filter searches using relevant terms of our discipline topics of interest, regional variation and thematic areas. Table 1 shows nine titles used to represent the HR discipline across the Middle East. It shows that the number of studies is greatest when the search is kept general with terms such as "human resource management," "personnel management" and "people management." However, abbreviations, such "HRM" and "HR" and "HRD" [human resource development] return far fewer number of studies.

Table 2 shows more disaggregated searches along the different countries (for which we found more literature) from the region. For 10 individual countries, as representative cases, we show the number of studies that focus on HRM and the Middle East. Among these 10 countries, the highest number of HR-related studies are for Egypt, Jordan and Saudi Arabia whereas Bahrain and Qatar are on the lower side of the spectrum. The table also shows the distribution of studies for seven sub-terms of the broader title or function (i.e., HRM).

Table 1 Titles used to denote the field of HRM in the Middle East

\begin{tabular}{lccc}
\hline & $\begin{array}{l}\text { Middle East } \\
\text { (includes GCC and MENA) }\end{array}$ & $\begin{array}{l}\text { Gulf Cooperation } \\
\text { Council (GCC) }\end{array}$ & $\begin{array}{l}\text { Middle East and } \\
\text { North Africa (MENA) }\end{array}$ \\
\hline $\begin{array}{l}\text { International human resource } \\
\text { management }\end{array}$ & 24,538 & - & - \\
Human resource management & 27,165 & 2319 & 7605 \\
HRM & 1308 & 87 & 203 \\
HR & 2431 & 181 & 536 \\
Personnel management & 8903 & 897 & 2339 \\
Human resource development & 5851 & 2269 & 7414 \\
HRD & 382 & 36 & 80 \\
People management & 23,687 & 2115 & 6809 \\
People-management & 358 & 23 & 59 \\
\hline
\end{tabular}


Table 2 Number of cross-country HRM studies

\begin{tabular}{lrrrrrrrrrrr}
\hline & Algeria & Egypt & Jordan & Morocco & $\begin{array}{l}\text { Saudi } \\
\text { Arabia }\end{array}$ & Kuwait & UAE & Qatar & Bahrain & Oman \\
\hline $\begin{array}{l}\text { Human resource } \\
\text { management } \\
\text { and the Middle East }\end{array}$ & 2244 & 7320 & 9419 & 3121 & 4693 & 2694 & 2412 & 1674 & 1579 & 2305 \\
$\begin{array}{l}\text { Of which } \\
\text { Human resource }\end{array}$ & 53 & 241 & 383 & 72 & 247 & 146 & 203 & 90 & 75 & 144 \\
$\quad$ management & 120 & 497 & 951 & 151 & 412 & 214 & 270 & 129 & 41 & 289 \\
$\begin{array}{l}\text { HR } \\
\begin{array}{l}\text { Personnel } \\
\text { management }\end{array}\end{array}$ & 641 & 2016 & 2866 & 762 & 1520 & 956 & 869 & 511 & 47 & 728 \\
$\begin{array}{l}\text { Human resource } \\
\text { development }\end{array}$ & 2167 & 7003 & 8779 & 3022 & 4492 & 2586 & 2318 & 1630 & 75 & 2204 \\
$\begin{array}{l}\text { HRD } \\
\text { People management }\end{array}$ & 1915 & 6216 & 7837 & 2539 & 3935 & 2292 & 2075 & 1419 & 71 & 1959 \\
People-management & 12 & 58 & 113 & 12 & 55 & 32 & 54 & 24 & 7 & 35 \\
\hline
\end{tabular}

Table 3 illustrates the distribution of studies across the eight most occurring thematic areas within the HRM literature. This distribution is shown for three regions (i.e., the Middle East, including the GCC and MENA, and then the GCC and MENA by itself). The interesting and key highlights of these searches are that "gender and HRM" returns the highest number of studies, followed by "talent management" and "expatriates." Quite surprisingly, and contrary to popular belief, at the low end of the spectrum we find themes such as "nationalization programs and HRM" ("Emiratization," "Omanization," etc.) and "factors including HRM" and "comparative HRM."

In order to address the two parameters of "quality" and "recentness," we further refined our search targeting articles published in journals listed in the Chartered Association of Business Schools (CABS) list, Australian Business Dean Council (ABDC) list and Social Sciences Citation Index (SSCI). On the homepage of each journal, the advanced search options were used to elicit relevant results. This time we

Table 3 Prominent thematic HRM areas

\begin{tabular}{lccc}
\hline & $\begin{array}{c}\text { Middle East (including } \\
\text { GCC and MENA) }\end{array}$ & $\begin{array}{l}\text { Gulf Cooperation } \\
\text { Council (GCC) }\end{array}$ & $\begin{array}{l}\text { Middle East and North } \\
\text { Africa (MENA) }\end{array}$ \\
\hline Comparative HRM & 759 & 49 & 134 \\
Challenges for HRM & 1027 & 78 & 172 \\
Factors influencing HRM & 388 & 26 & 63 \\
HRM and performance & 1201 & 81 & 185 \\
Gender and HRM & 8984 & 596 & 2775 \\
Talent management & 3452 & 283 & 1096 \\
Nationalization programs and HRM & 41 & 20 & 13 \\
Expatriates & 1956 & 324 & 717 \\
\hline
\end{tabular}


extended our search to a variety of datasets including Proquest, ESBCO, and books and from the webpages of relevant journals. Building on our above presented search and analysis, we used the following keywords and themes in our search: "Middle East; management practices in Middle East; Middle East and HRM practices, policies, strategies, and systems; Middle East and HR planning, recruitment, selection, training, development, performance management, rewards, compensation, talent management; HR challenges in the Middle East; determinants of HRM/factors influencing HRM in the Middle East; comparative HRM and Middle East; nationalization programs and HRM; gender; expatriate management; Islamic principles and values and HRM; future research in HR in the Middle East," in combination with each of the main countries in the region without limiting the time frame. The findings of the studies on the parameters of quality and recentness are summarized in Tables 4, 5, and 6 under the headings "The socio-business context of the Middle East," "The challenges of future for HRM in Middle East" and "Recent thematic findings on HRM in Middle East" respectively. These findings are summarized in these three tables and are helpful to provide an overview of the state of HRM development in the region, reveal the institutional forces that contribute to such development and propose evidence-based directions for future research.

\section{Analysis and discussion}

After analyzing the existing frameworks suitable for analyzing cross-national contextspecific HRM (see Budhwar and Debrah, 2009; Budhwar et al., 2016 for a review of such frameworks), we focused our analysis on the reviewed literature related to the historical development of the HR/personnel function in the Middle East; the key factors determining HRM practices and policies (such as labor markets, national business systems, national culture, societal effects, competition, business environment, different institutions, etc.; following the above-discussed underpinnings of the institutional theory, see Powell \& DiMaggio, 2012; Scott, 2008); the key challenges being faced by the HR function; and finally, the future of HRM in the region. An examination of these aspects should help highlight developments in HRM, as well as predict future practice trends, and generate research ideas for future investigations.

Picking up the review of literature reported in Tables 4, 5 and 6, a variety of reasons can be identified for the poor economic performance of the region (with the exception of few countries like the UAE [United Arab Emirates]). For example, lagging political reforms; dominant and underperforming public sectors; underdeveloped financial markets; high trade restrictiveness; and inappropriate exchange regimes. Along with these, the slow economic growth in the region can also be attributed to a combination of other factors such as the so-called curse of natural-resource abundance (over-dominance of the oil sector in oil-rich countries); structural imbalances (traditional mind-sets and systems versus need for modernization); deficient political systems; slow integration into the global economy; inefficient public sectors; rapidly growing population and increasing unemployment rates; lack of access to quality education; lack of creation of employable skills; strong inclination of many locals in Gulf state countries to work only in public sector firms (hence defeating the purpose of the nationalization programs), and similarly, in managerial positions; over-reliance on foreign workforce; underutilization of skilled women; and red-tape and adverse implications of indigenous practices like "wasta" - a relationship-based approach to recruitment and 


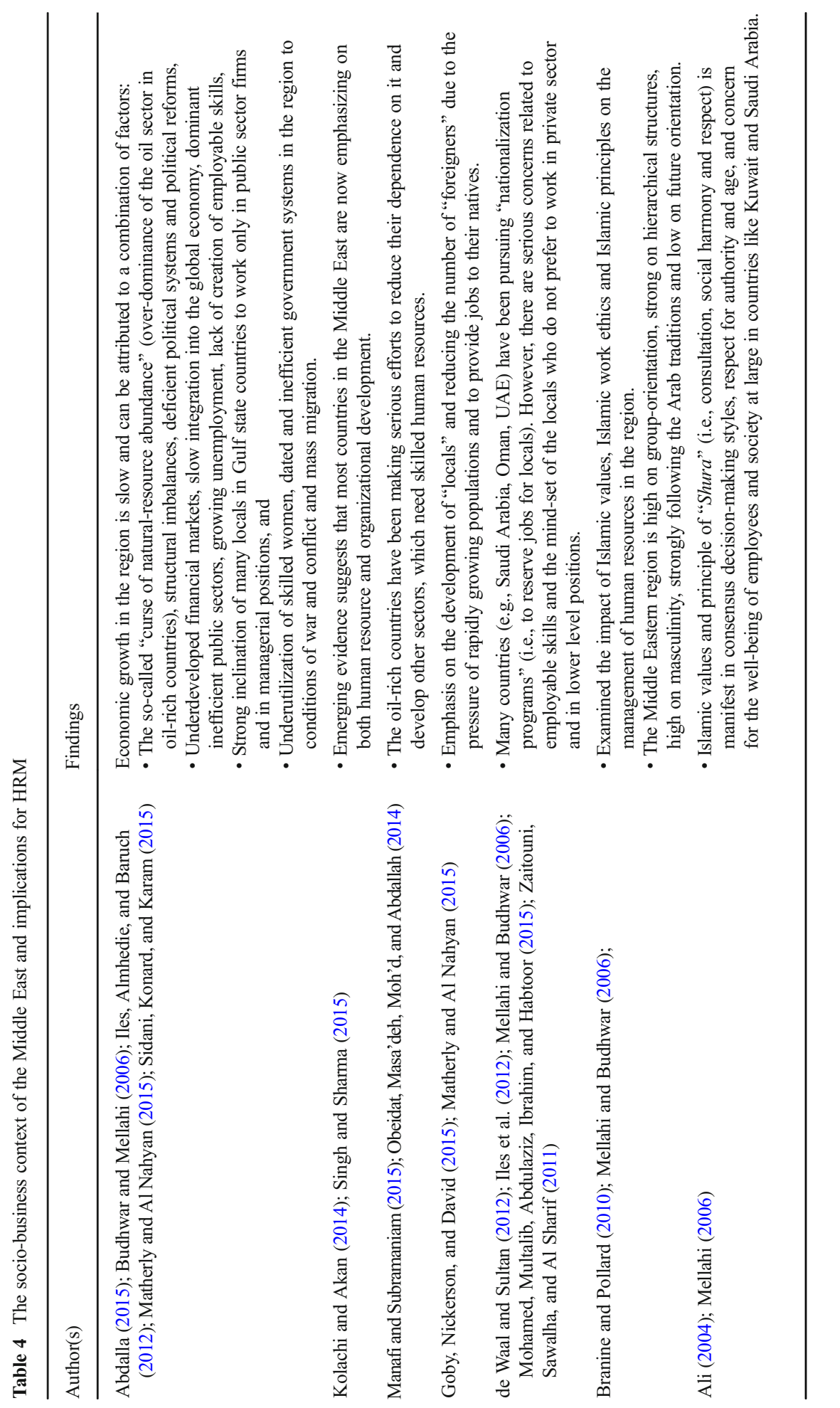




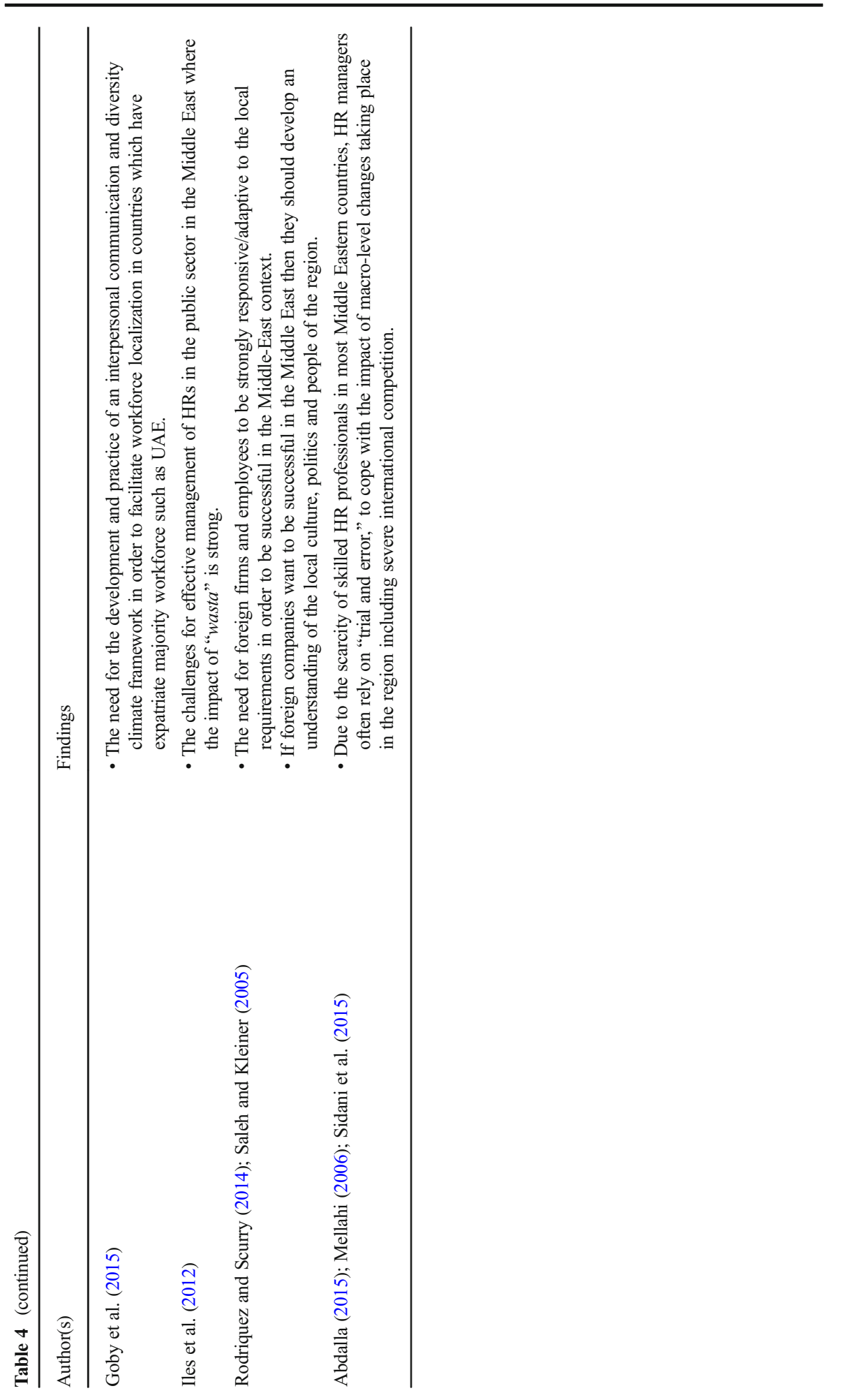




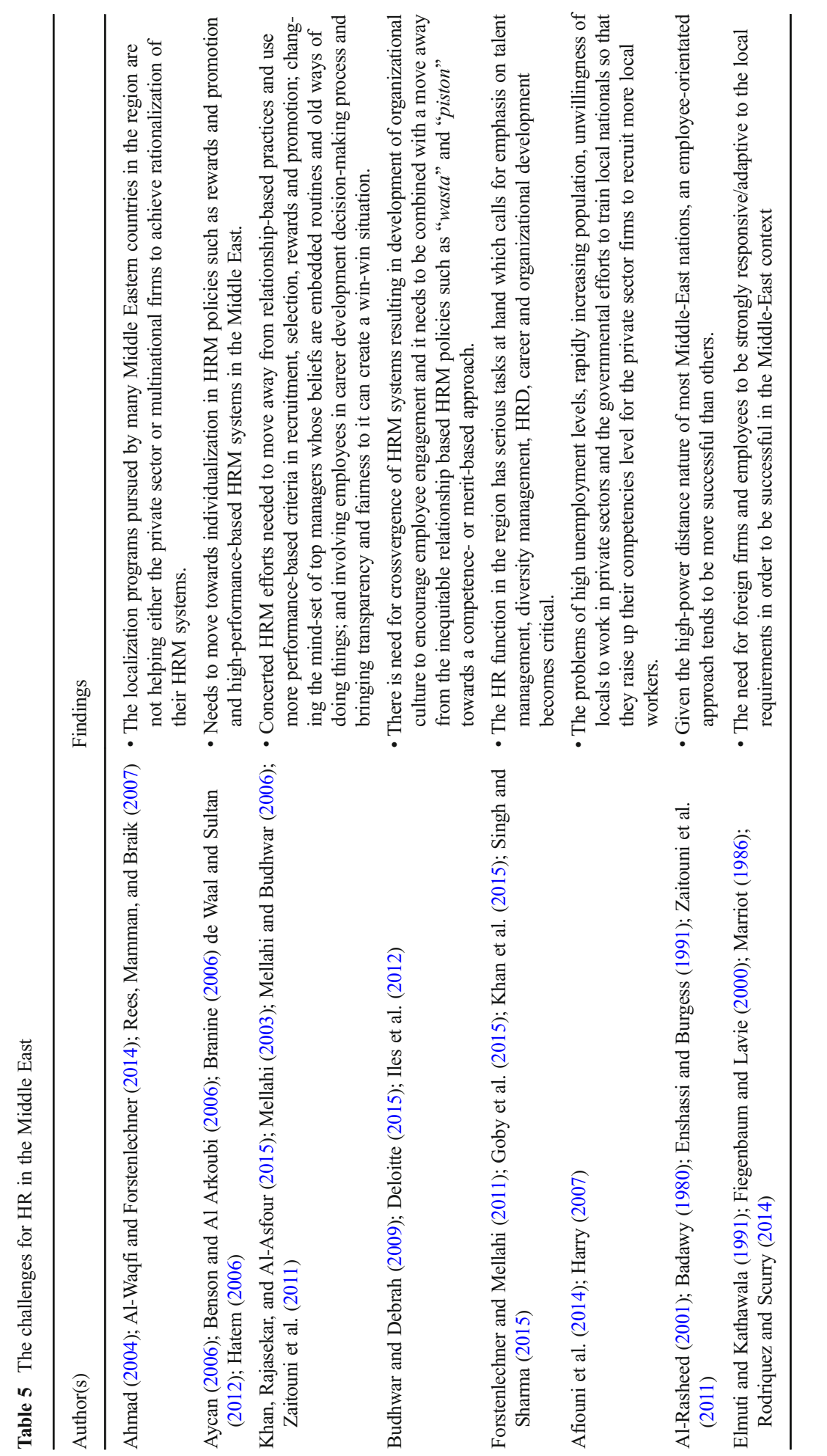




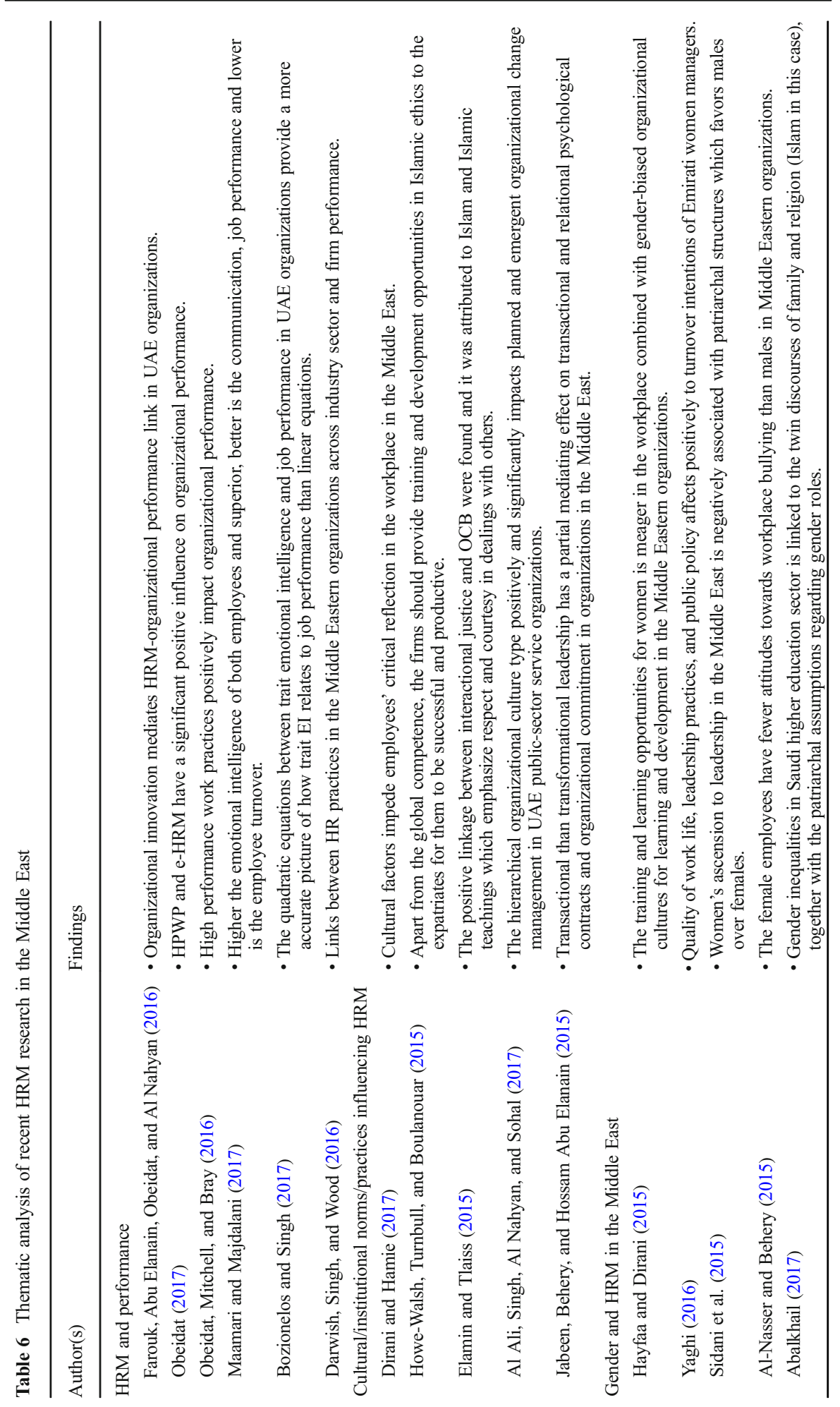




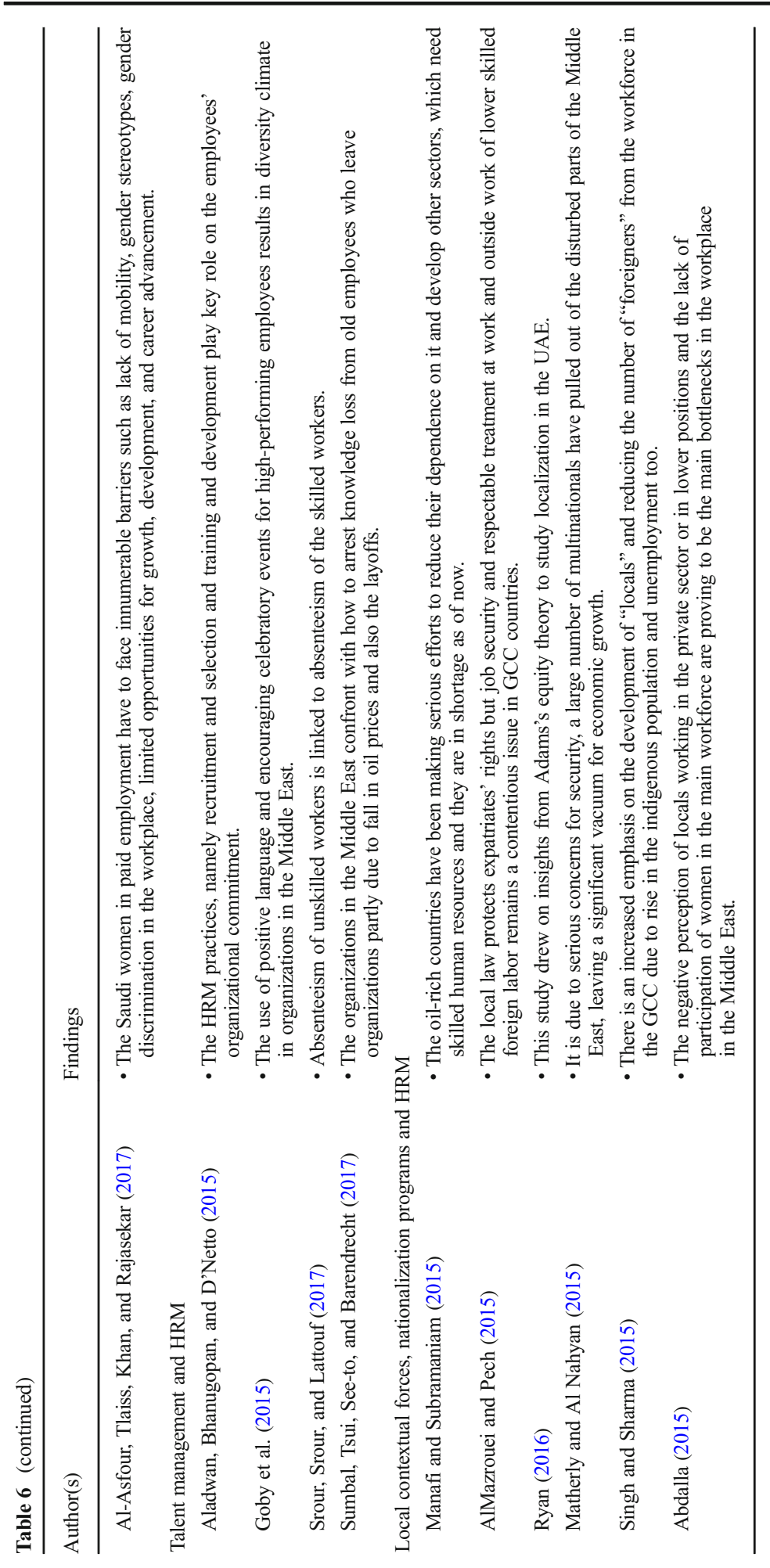


compensation (detailed below), among others (see Abdalla, 2015; Harry, 2016; Sidani et al., 2015).

Moreover, the kind of government system existing in the region seems to be contributing to the slow economic growth of the region. Traditional sheikhdoms and absolute monarchies dominate in virtually all of the Arabian Peninsula. The rest of the region has been dominated by military and other autocratic regimes claiming allegiance to socialist, Arab nationalist or Islamist ideologies. Some states have taken tentative steps towards forms of multi-party democracy in recent years, but widespread economic underperformance and the lack of opportunity for political expression have led to the conditions of war and conflict, mass migration and social disruption. Expectedly then the Middle East is the highest military spending region of the world. Such developments have serious implications for foreign direct investment (FDI) in the region, and due to serious concerns for security, a large number of multinationals have pulled out of the disturbed parts of the Middle East and there are also indications of "brain drain" taking place, leaving a significant vacuum in terms of economic growth. Also, these developments have many socio-economic and HR implications, such as dealing with increasing unemployment, retention of talent and overall human capital management (e.g., Goby et al., 2015; Singh \& Sharma, 2015).

Emerging evidence (see Tables 4 and 6) suggests that most countries in the Middle East are now focusing on both HRD and organizational development (see Kolachi \& Akan, 2014). In particular, the oil-rich countries have been making serious efforts to reduce their dependence on oil and develop other sectors, which need skilled human resources (e.g., Manafi \& Subramaniam, 2015; Obeidat et al., 2014). Similarly, many countries in the region have been concentrating on the development of "locals" and reducing the number of "foreigners" due to the pressure of rapidly growing populations, and to provide jobs to their natives (see Goby et al., 2015; Matherly \& Al Nahyan, 2015). In this regard, many countries, such as Saudi Arabia, Qatar, Kuwait, Oman and the United Arab Emirates, have been pursuing "nationalization/localization programs." A key pillar of localization programs is direct labor market intervention with measures such as quotas and the allocation of certain job roles to be staffed solely by nationals.

The literature shows variations regarding the initiatives being offered across nations in support of the localization programs. For example, the region's latest localization program has come from the UAE where a tier-based system of targets, with financial incentives and penalties designed to encourage firms to achieve higher levels of workforce localization, is being pursed. Under the new rules, allowing them to pay lower fees to process visas for their expatriate employees will reward companies achieving higher localization levels. In comparison, Bahrain effectively taxes the use of expatriate labor, directly raising its cost relative to the use of national employees. Oman stands out as an interesting case with respect to localization. Probably more than in any other GCC nation, Omanis have been willing to take jobs that would have been filled elsewhere by low-wage foreign workers (perhaps due to the fact that Oman is not very oil rich and job opportunities are fewer then other GCC countries (also see Waxin \& Bateman, 2016).

With the exception of few notable successes, most localization efforts have failed to deliver significant growth in the employment of nationals in the private sector. Many local workers are simply not interested in private employment paying market rates that 
are below public service salaries and which offer more limited benefits than government jobs. Further, there are serious concerns related to employable skills of locals. Such developments have serious implications for the HR function in the region and in particular in relation to its role towards improving organizational performance (Iles et al., 2012; Mohamed et al., 2015; Waxin \& Bateman, 2016).

As reported in Table 2, a significant chunk of this research in the region focuses on providing a country-specific overview. Our analysis highlights the emerging patterns of HRM, HR issues and related systems along with their key determinants in selective countries. In this regard, see work by Al-Hamadi, Budhwar, and Shipton (2007), Katou, Budhwar, Woldu, and Al-Hamadi (2010), Khan (2011) and Khan et al. (2015) on Oman; Aycan (2001) on Turkey; Elamin and Tlaiss (2015) and Mellahi and Wood (2004) on Saudi Arabia; Manafi and Subramaniam (2015), Namazie and Frame (2007), Namazie and Pahlavnejad (2016) and Soltani and Liao (2010) on Iran; Omair (2010) and Singh and Sharma (2015) on UAE; Al-Enzi (2002) and Zaitouni et al. (2011) on Kuwait; Altarawneh and Aldehayyat (2011) and Syed, Hazboun, and Murray (2014) on Jordan; Tzafair, Meshoulam, and Baruch (2007) on Israel; Leat and Al-Kot (2007) and Mostafa and Gould-Williams (2014) on Egypt; and Branine (2004) and Ramdani, Mellahi, Guermat, and Kechad (2014) on Algeria.

For example, an analysis by Al-Jahwari and Budhwar (2016: 115) highlights that "HRM is a growing phenomenon in Oman but its practices are still largely traditional and reactive. The various HR processes are often designed with Western practices in mind, but when carried out, the practices are often not well aligned to business strategies, they are implemented for narrow administrative purposes and remain loosely connected to each other." It seems that a mixture of Islamic principles and Western approach to management of HRs seem to be influencing HRM in Oman. This is further evidenced from Aycan, Al-Hamadi, Davis, and Budhwar's (2007: 30) analysis, where "on the one hand, there is an increased emphasis on Omanization and adherence to Islamic principles yet, on the other hand, globalization imposes pressures to adopt global standardized HRM practices and policies."

Other themes emerging from our analysis include an emphasis on training and development in general and management development in particular, the effects of regulations on HRM in the Saudi Arabian private sector (Mellahi, 2007) and on employment policy in Kuwait (Al-Enzi, 2002), the impact of HRM on organizational commitment in the banking sector in Kuwait (Zaitouni et al., 2011), the efficacy of high-performance work practices in Algerian firms (Ramdani et al., 2014), the impact of HRM practices and corporate entrepreneurship on firm performance in Turkish firms (Kaya, 2006), talent management strategies in the UAE (Singh \& Sharma, 2015), the impact of cultural value orientations on preferences for HRM (Aycan et al., 2007), HRM and labor productivity in Libyan oil companies (Mohamed et al., 2015), HRM and innovation in the Iranian electronics industry (Manafi \& Subramaniam, 2015) and career development in Oman (Khan et al., 2015).

Raheem (2016: 77), concluding her analysis about the scenario of talent management in the Middle East, argued that "recent trends in the demographics of the local population, intensified demand for talent, the changing aspirations of the youth and women and the limited application of sound talent management practices, all make talent management issues even more challenging for organizations in the Middle East than in other parts of the world." She further elaborated that "historical precedents of talent management in the region have further hampered the sustenance of equitable 
working environments for both locals and expatriates. This combination of institutional and organizational factors has, in turn, put immense pressures on the criticality, development and implementation of talent management systems for organizations operating in this region."

Over the past quarter of a century or so (also see Table 6), there has been a consistent emergence of gender-based studies in particular dedicated towards women in management-related issues, in the context of Middle Eastern countries. For example, see research by Ali, Malik, Pereira, and Al Ariss (2016) on work life balance of Muslim migrant women in the West. Also, see the works of Abdalla (2015) and Tlaiss (2015) for career success/facilitators and barriers for women in an Arab context; Sidani et al. (2015) for female leadership advantage and leadership deficit; Marmenout and Lirio (2014) for female talent retention in the Gulf; Metcalfe (2008) for women in management in the Middle East in general and in particular for Bahrain, Jordan and Oman; Aycan (2004) for Turkey; Metle (2002) for Kuwait; and Izraeli (1987) for Israel.

Apart from gender, another theme which our analysis highlights (see Tables 4, 5 and 6) is that of the influence of Arab culture and values on its management systems (e.g., Ali, 2010; Dirani \& Hamie, 2017; Mellahi, 2003). A related focus of research has been to examine the impact of Islamic values, Islamic work ethics and Islamic principles on the management of human resources in the region (see Branine \& Pollard, 2010; Budhwar \& Mellahi, 2010). Islam places great emphasis on work and views work as a necessary means to achieve equilibrium in one's social and individual life (e.g., Ali, 2010). Islam also places emphasis on work ethics, management and leadership. The Holy Quran speaks about justice and honesty in trade, fairness in employment relationships, encourages new skills to be learned, co-operation in work, consultation in decision-making and to do work that benefits the individual and the community (Branine \& Pollard, 2010). Such prescriptions have a strong influence on how human resources are managed in organizations, work-related values, the expectations of employees as well as the behavior and approach of management (Aycan et al., 2007).

Following are some relevant Islamic principles and their relevance to HRM (Branine \& Pollard, 2010; Budhwar \& Mellahi, 2010): (1) "Ehsan" (kindness) emphasizing on good deeds and forgiveness. Managers scoring high on this principle are expected to pursue involvement and participation; (2) "Taqwa" (being mindful of Almighty God) to behave in a just and steadfast manner; (3) "Al-Amanah" (trust) in relationships leading to accountability; (4) "Adl" justice) emphasizing on equality and fairness having implications for most HR functions; (5) "Al-Sedq" (truthfulness) to the best of one's knowledge leading to honesty and trustworthiness as core features of effective management; (6) "Etqan" (self-improvement) which provides the basis for one's striving for self-betterment in order to do better work. In HRM this would translate to do better, work harder and improve the quality of their products and services through the learning of new knowledge and skills; and (7) "Shura" (consultation, social harmony and respect). Consultation is one of the main leadership values in Islam. Accordingly, Islam may influence workplace behavior with values such as respect for age and seniority, loyalty, obedience towards leaders and looking to seniors for direction, consultative decision-making, trustfulness both between superiors and subordinates (Al Ali et al., 2017; Namazie \& Tayeb, 2006; Namazie \& Venegas, 2016).

As expected, due to socio-cultural similarities, a number of countries (such as Egypt, Morocco, Turkey, Kuwait and Qatar) tend to be similar on various aspects of cultural 
value orientations, such as strong on group orientation, hierarchical structures, masculinity and following Arab traditions and weak on future orientation (see Kabasakal \& Bodur, 2002). Mellahi and Budhwar (2006) revealed the influence of high power distance on managers' perception towards the delegation of authority to lower levels of employees and interaction with employees in countries like Morocco, Kuwait, Saudi Arabia and Egypt. They also highlighted that in such contexts and socio-cultural and traditional set-ups, loyalty to one's family and friends is expected to override loyalty to organizational procedures and this often results in the use of inequitable criteria in recruitment, promotion and compensation. Ali (2004) and Mellahi (2006) further highlighted that the influence of the principle of shura is manifested in consensusbased decision-making styles, respect for authority and age, and concern for the wellbeing of employees and society at large in countries like Kuwait and Saudi Arabia. On the contrary, Ali and Al-Kazemi (2006) revealed that several ideal Islamic values such as equity and fairness are often not adhered to in practice. This explains the widespread adoption of some HRM practices in the Middle East that are not compatible with Islamic values, such as the use of nepotism in recruitment and compensation, known as wasta in GCC countries and "piston," " $m$ 'aarifa" and " $k$ 'tef" in North African countries. Similarly, Iles et al. (2012) highlighted the challenges for effective management of human resources in the public sector in the Middle East where the impact of wasta is strong.

Scholars have been examining the issue of transfer of management from the West to the Middle East. For example, Anwar (2003), while comparing American and Arabian culture, highlighted a number of differences between the two and how the American management philosophy and styles in the US multinationals operating in the Middle East are adapted to suit the cultural context of the UAE. Analysis by Saleh and Kleiner (2005) gives a similar message (i.e., if American companies want to be successful in the Middle East then they should develop an understanding of the culture, politics and people of the region). With regard to the transfer of HRM practices, the results are similar. For example, Elmuti and Kathawala (1991) examined the extent to which Japanese HRM practices can be transferred to their subsidiaries in the Arabian Gulf region. Their investigation revealed that either largely modified version of Japanese-style management or a brand-new management style composed of elements of local and Japanese management practices were successful in the given context.

Further, a number of trends are emerging from our analysis which seem to be shaping the practice of HRM in the region. They include (1) increased presence and influence of multinational enterprises (MNEs), through FDI, and so forth; (2) the moving away of traditional practices by local players with global ambitions (towards globalization); (3) the rapid growth of global business schools to the Middle Eastboth as foreign subsidiaries as well as local partners; (4) reliance on management consultants and "gurus," especially on experts from developed countries; and (5) dominance of Western textbooks and best-sellers (see Budhwar \& Mellahi, 2016; Ramdani et al., 2014). Although the jury is still out on the effectiveness of MNEs' practices in the Middle Eastern context, there is evidence that they are shaping HRM practices in the region as they have done for other regions such as South-East Asia (Thite, Wilkinson, \& Shah, 2012). However, our knowledge of the extent to which and the manner and speed with which MNEs' practices are diffused locally is very limited. More research is needed, especially research examining local firms' absorptive capacity 
to identify, absorb and apply MNEs' HRM practices. Such challenges facing the HRM function in the Middle East and the resultant future research directions are presented in the next section.

\section{Challenges for HRM and future research directions}

Our analysis highlights how the field of HRM continues to evolve in the Middle East and the rapidly changing socio-political and economic environment of the region is posing a large number of challenges for the HRM function. From a research viewpoint, especially given the strong scarcity of the availability of reliable evidence, this offers huge opportunities to pursue exciting research projects. We utilize the key messages emerging from our above presentation to make our proposals. For example, talent management is one of the key challenges facing firms operating in the Middle East (Ali, 2011; Biygautane \& Al Yahya, 2014; Sidani \& Al Ariss, 2014; Sumbal et al., 2017). Existing evidence suggest that there is a huge demand-supply gap when it comes to talent in the region. There are at least two key drivers for this. The education system is largely failing to produce an adequate supply of talent. This is largley due to the lack of relevance and quality of education provided by academic institutions which are often considered as the bottleneck of economic development in the region (e.g., Chapman \& Miric, 2009).

The second driver is the brain drain through imigration of home-grown talent to Europe and other parts of the world. Moreover, political instability in several Middle Eastern countries has accelerated the outflux of talent from the region. In addition to the supply side, organizations lack the required managerial skills and systems to attract, retain and obtain the best out of highly talented individuals. Current recruitment, compensation and retention practices seem to be effective only for the management of high-performing employees, leading to what is called "brain waste" in the region, that is, where the skilled and the educated leave their home country (both from the Middle East and coming into the Middle East), but then either make little use of their skills and education or are forced to take on jobs which can be performed by lower skilled individuals. Accordingly, on the key variable of earnings as a measure of performance, the immigrants' earnings generally tend to be low (especially those coming from non-Western countries) in comparison to locals and Western expatriates. In this regard, see the report by Özden (2006) on the MENA region and also work by Lofters, Slater, Fumakia, and Thulien (2014) on medical graduates in Ontario, Canada. Effective talent management then requires a change in mindset and an appreciation of the valuable and unique contribution high-performing individuals can make to their organizations. Overall, talent management is a promising and fertile area of future research. Based on our above argments, we propose our first two "research directions":

Research Direction 1 What are the main contributors to the creation of poor talent in majority of the Middle Eastern countries? What role can HR managers play to attract and retain talent and what should be their strategies and why?

Research Direction 2 To identify and examine the linkages between antecedents, intervening variables and outcome variables of talent management in the Middle East. 
As discussed above, and linked to the theme of talent management, are a range of issues surrounding the provisions, communicaiton and implementation of nationalization/localization programs in many Middle Eastern countries. These programs are formally defined as "a multi-level process through which dependency on the expatriate labor force is reduced and nationals are prepared to take up jobs performed by expatriates" (Abdelkarim, 2001: 56). Such an initiative (i.e., Emritization, Saudization, Omanization, Kuwaitization, Qatarization, Bahraizisation, etc.) is linked to long-term national strategies and visions such as Bahrain 2030 Vision, the National Saudisation Policy, Qatar Vision 2030, Oman Five-Year Strategic Plan, Kuwait Development Plan and UAE Strategy 2011-2021 all emphasizing on human development. Clear labor legislations are created to support implementation of the localization programs, and as a result large firms operating in these countries (primarily in the GCC) are forced to develop some plan to address the localization of HRs agenda of respective governments. This has implications for a variety of HR activities such as recruitment and selection, training and development, career management, performance management, compensation and talent management (e.g., Scott-Jackson, Porteous, Gurel, \& Rushent, 2014).

Evidence suggests some success with the implementation and benefits of localization programs. Nevertheless, there are serious challenges on this front where firms experience pressure to lower the selection standards, struggle to create a strong pool of applicants, and not getting applicants with good work experience. As reported above, to a great extent this is an outcome of the shortcoming of the educational system of the region and lack of market-related skills and experience available within the local nationals. Employers tend to invest a lot and highlight the professional development practices to attract and develop talent. In some cases, employers end up compromising by creating "ghost registers" (i.e., showing locals on their employment records, but asking them to stay at home and pay for their minimum contributions) and adopting other means to bypass restrictions and quotas to meet the localization requirements. Employers in the private sector in particular experience a number of socio-cultural challenges in effectively implementing localization programs. These include the strong preference of locals to work in the public sector, where the social status of the job is important for locals. In addition, there is some level of discomfort for locals when it comes to them being supervised by non-nationals, alongside the lack of integration efforts by expatriates with locals and negative stereotypes of both locals and expatriates towards each other (Abdalla, 2015; Al-Waqfi \& Forstenlechner, 2014; Ryan, 2016). This creates serious challenges of all sorts for the HR function (for details see Waxin \& Bateman, 2016). Based on the above discussion our next set of research directions are:

Research Direction 3 What kind of approaches need to be put in place in order to design, communicate, implement and monitor successes of localization programs?

Research Direction 4 Identify the key challenges HR is expected to face at different levels (national, firm and individual) and what are the best ways to address them when it comes to the successful delivery of the localization agenda?

A linked topic to the above discussed HR challenges and future research directions is the practice of wasta, which is a major HR challenge, especially when it is perceived as contributing to nepotism and corruption at the work place and it goes against the 
Islamic principles of practice of equity and fairness. Wasta (going in between) is described as a powerful and pervasive social mechanism, which has strong roots in cultural traditions and known to underpin the employment relationship in Arabic societies. It can be seen as "the intervention of a patron in favour of a client to obtain benefits and/or resources from a third party" (Mohammad \& Hamdy, 2008: 1). It involves the wasta person (intercessor) who does the wasta (verb) and the wastee (supplicant) who receives benefits (called objects), sometimes from a third party. It is defined as a process whereby one may achieve goals through links with key persons in positions of higher status. These links are personalistic, and most often derive from family relationships or close friendships (Cunningham \& Sarayrah, 1993). Wasta is then a form of social capital, associated with loyalty and solidarity, resulting in an unwritten social contract and a hidden force or an invisible hand, which is not confined to support, and favoritism provided to family members, such as nepotism, but involves several other relationships such as cronyism, kinship, colleagueship, friendships, and business relationships (for details see Ta'Amnha et al., 2016). In their research on indigenous approaches to achieve influence, Smith et al. (2012: 348) have utilized the below statement as an example to highlight interpersonal influence to represent the practice of wasta.

"Tom is a recent graduate from a local university. He called his uncle in order to help him to get a position in a retail company without applying through that company's recruitment procedures. His uncle, who is a general manager in another large company, contacted the human resources manager in the retail company and requested him to recruit his sister's son. In fact, after one week, Tom got the position without going through any recruitment procedure."

Accordingly, one aspect of wasta involves bypassing the law and obtaining favors and benefits at the expense of other people; therefore, it is widely opposed by Arabic people. Despite being a punishable crime in certain countries (e.g., Jordan), the prevalence of wasta in organizations in the region is on the increase because it is proving to be impossible to overcome bureaucratic obstacles in any other way. To a great extent it is due to the lack of transparency and accountability at all levels (organizational and national), lack of trust between people and government/authorities who try to maintain a grip on authority to govern, its informal institutionalization (i.e., the belief that it is one's right to access resource via such means), lack of protection of employees' rights via labor legislation resulting in people to rely on it to protect themselves, and to a great extent the race to access scarce jobs and related benefits. The detrimental outcomes of the practice of wasta include lack of competence in employees, unprofessional behavior, perceptions of ill-justice, resentment and risk of retaliation, destruction of equality and fairness at the workplace, results in unfair practices, and impacts careers, to name a few (also see Iles et al., 2012). Indeed, and most importantly, all of these also have implications for the HR function. Despite its strong prevalence in the Middle East, and increasingly strong opposition growing against it, not much research and evidence is available on various aspects of wasta. These can include the process of wasta, its influences, downsides and usage, and how it is perceived by the younger generation and organizations, both local and foreign and public and private sector (e.g., Aldossari $\&$ Robertson, 2015). Based on the above discussion, we propose three further research directions: 
Research Direction 5 What are the key challenges facing the HR function when it comes to tackling the adverse impacts of the practice of wasta and what are the various ways/recommendations to handle them?

Research Direction 6 To develop a robust research scale of wasta and identify the key antecedents, intervening variables and outcome variables involved in its process.

Research Direction 7 To explore the impact of wasta on HRM efficiency and effectiveness and eventually on organizational performance in the Middle Eastern context.

The region of the Middle East scores very high on the use of domestic workers/ migrant workers in the world, with domestic work accounting for $5.6 \%$ of total employment in the region and majority of these workers come from Far East and Africa (e.g., the Philippines, Thailand, Indonesia, Nepal, Myanmar, Sri Lanka, Ethiopia, Kenya). Evidence regularly highlights issues of abuse, modern day slavery, mistreatment, and exploitation of domestic workers in the region. Most of these workers arrive in the Middle East via recruitment agencies. Accordingly, domestic workers are not allowed to self-sponsor themselves to be able to work in most Middle Eastern countries. In many countries they may do so only if they have a local sponsor (a local employer), this sponsorship system is known as "kafala." The kafala places full legal responsibility on the employer known as the "kafeel" (Manseau, 2007). The sponsorship system is rigid in the sense that it is nontransferable to another employer and the domestic worker has to stick to one employer. A migrant worker is unable to get another job (with another sponsor) unless their current sponsor approves the transfer. This results in all sorts of issues and many a times serious exploitation. In many cases, employers of the domestic workers confiscate their employees' passport in order to control and retain them. When an employee somehow gets away, their kafeel immediately reports the missing employee to the authorities. Once found, the runaway employee could face deportation. Moreover, legal action is taken against any individual that shelters or employs migrant workers without a kafala. This has major implications for employment relations and human rights in particular and the HR function of recruitment agencies and the national legislation in general (see Pande, 2013).

All Middle Eastern countries, with the exception of the Kingdom of Jordon do not include domestic workers in their labor laws. The reason why domestic workers are not included in Middle Eastern labor laws is because governments in the Middle East claim that the relationships between migrant domestic workers and their employers are more like family relationships rather than formal employment relations. To a great extent, similar terms and conditions of employment are also applicable to migrant low-skilled workers in the region employed by a large number of organizations involved in industries like construction and the informal sector, where evidence of under-payment (or at times non-payment) of wages, poor working conditions and exploitation of all sorts is regularly emerging in the popular press (e.g., Al-Ajmi, Hirekhan, Budhwar, \& Singh, 2016; Guardian, 2015). Based on the above discussion, we come up with three further research directions:

Research Direction 8 To examine and highlight the dynamics of employment relationship between overseas domestic workers and their employers in the Middle East. 
Research Direction 9 What suggestions and recommendations can be made at different levels (recruitment agency, individual employers, employing organizations and national) to ensure safeguarding of domestic migrant workers in the Middle East?

Research Direction 10 To examine and highlight the nature and pattern of HRM systems in the informal sector of countries in the Middle East, and their impact on performance at different levels (individual, organizational and national).

The next key topic emerging from our analysis is related to the transfer of HRM practices by overseas MNCs to the Middle East. One outcome of the passage of Western MNCs to the region has been the transfer of their HR systems to their Middle Eastern operations (e.g., Dowling, Festing, \& Engles, 2013). In this regard, scholars have regularly looked at the challenge of the application and successful transfer of Western MNCs' HR practices in the Middle Eastern context (e.g., Mellahi, Demirbag, Collings, Tatoglu, \& Hughes, 2013; Nakhle, 2011; Spyridonidis \& Currie, 2016). The patchy evidence emanating from the literature portrays a mixed picture, that is, the strong socio-cultural and institutional context of the region demands foreign firms to adapt their headquarter HR practices to suit the Middle Eastern set-up. Research by Yahiaoui (2007, quoted in Al-Husan \& AlHussa, 2016) regarding the transfer of HR practices from French MNEs to their Tunisian subsidiaries reveals that certain practices are strongly hybridized or unilaterally transferred, as is the case with career management. Other HR functions are said to be neutral or insensitive and are either moderately transferred or moderately hybridized, for example compensation or recruitment. This creates an interesting dilemma for the HR manager in choosing which approach to adopt when it comes to developing their HRM systems. Accordingly, we propose our next research direction.

Research Direction 11 To highlight the main factors contributing to the successful implementation (or otherwise) of Western approaches to HRM in the Middle Eastern context.

Although a very large number of expatriates work in the Middle East, the research conducted on the management of expatriates is scarce. As briefly portrayed in our introduction, analysis by Harrison and Haslberger (2016) confirmed that the expatriate population in four countries in the region is more than half of their total population (i.e., $\mathrm{UAE}=83.7 \%$, Qatar $=73.8 \%$, Kuwait $=$ $60.2 \%$ and Bahrain $=54.7 \%)$. This is followed by Jordan $(40.2 \%)$, Saudi Arabia $(31.4 \%)$ and Oman $(30.6 \%)$. Understandably then, there is a strong emphasis on the above discussed nationalization/localization programs in the region. Expatriates are generally given short-term work visas, which need to be renewed regularly and they are discouraged to become citizens. Given the massive crosscultural differences between expatriates (in particular those coming from the West) and local context, one can expect serious challenges with adjustment of expatriates, affecting their expected and perceived performance (e.g., Silbiger et al., 2017). This further makes things challenging if the expatriates do not follow Islam, given they are expected to respect Islamic principles and an evolving Islamic HRM model (Afiouni, Karam, \& El-Hajj, 2013). The literature also provides evidence that based on a variety of demographic variables (e.g., race, ethnicity, religion, gender, etc.), the host country nationals tend to put expatriates into in-groups 
and out-groups and accordingly this has implications for the expatriates' adjustment and performance (e.g., Varma et al., 2016). This indeed creates massive integration and diversity management challenges for the HR function (also see Forstenlechner, 2010; Harrison \& Michailova, 2012). Based on these arguments, we propose two further research directions.

Research Direction 12 What kinds of expatriate management programs are suitable for the Middle Eastern context? What should be their core content?

Research Direction 13 To identity and examine the main antecedents and their link with intervening variables on the expatriate success in the Middle East.

Our literature analysis also reveals that the HR function (especially in local and national firms, and in small-to-medium size firms) is still playing a reactive role and in many cases, there is no HR departments in organizations or even representation of HR at the board level (e.g., Budhwar et al., 2016). Nevertheless, and based on observations from other parts of the world, we believe that as countries within the region continue to economically grow and become more competitive, it is critical that the nature of their HR function also evolves and becomes more strategic. To some extent this is already happening in the UAE in particular (see Afiouni et al., 2013). Such a recognition and empowerment is a major challenge and frustration for the HR function.

The relationship between HRM practices and organizational outcomes has been the subject of increased research attention in the Middle East (Afiouni et al., 2014; Ancarani, Ayach, Di Mauro, Gitto, \& Mancusco, 2016; Moideenkutty, Al-Lamki, \& Sree Rama Murthy, 2011; Ramdani et al., 2014). Most of the studies have concentrated on HRM systems, such as high-performance work practices (HPWP) (Obeidat, 2017; Ramdani et al., 2014), with little research focusing on single HR practices such as selection, promotion and compensation. For instance, meritbased compensation systems are widely perceived to have a positive impact on performance but this presumption has not yet been verified empirically, in the Middle Eastern context. Research on the links between competitive strategy, HR practices and the firm performance is long overdue (e.g., Su, Guo, \& Sun, 2017). Accordingly, we present our next set of research directions:

Research Direction 14 To examine the evolving strategic role of HRM in firms operating in the Middle Eastern region, and the impact of HRM systems, policies, and practices on organizational performance.

Research Direction 15 To identify and highlight the key mediators and moderators (intervening variables) in the HRM and firm performance linkages in the Middle East.

\section{Conclusion}

With the growing business interest in the Middle East, both academics and practitioners are interested in finding out about the kind of HRM systems suitable for the region. As highlighted above, the challenges facing HRM in the Middle East are complex and unique. There is emerging evidence that HRM is undergoing transformation in the region, but it is unclear what the outcome of this transformation would be. Possibly, a hybrid system (based on a mixture of both traditional Middle Eastern characteristics 
and Western rationalized system) would emerge. In order to highlight the dynamics surrounding the evolving patterns of HRM in the region, although a variety of theoretical frameworks can be adopted (e.g., the resource-based view of the firm, human capital and role behavior theories; for details see Jackson \& Schuler, 1999), however, considering the significant above discussed socio-cultural and institutional influences on HRM in the Middle East, we believe both institutional (e.g., Scott, 2004, 2008) and indigenous theories would be a useful starting point (e.g., Leung, 2012; Saini $\&$ Budhwar, 2008). The adoption of institutional theory for our analysis has been helpful to understand the context-specific nature of HRM and its development to present state. Further, the analysis focusing on the key contextual/institutional (e.g., economic, social, political) forces as the key determinants of developments of HRM and the resultant challenges facing the HR function in the Middle East has been helpful to not only highlight state of HRM in the region but also to set the agenda for future research.

Also, based on the above analysis about the current state of HRM in the Middle East we believe a basic "directional convergence" is emerging for the field, that is, the same factors are determining both the nature of HRM and the challenges facing the HR function in the Middle-Eastern context (for details on different types of convergences, including the debate on convergence-divergence thesis; see Brewster, Mayrhofer, \& Cooke, 2015). This is clearly evident in the form of common institutional pressures dictating many countries in the region to pursue nationalization programs and emphasize on the development of their local human resources, which have clear implications for the evolving nature and patterns of HRM. Similarly, there is strong evidence to confirm the critical role played by the indigenous practices/constructs like wasta and others on the management of human resources in the region (for details see Budhwar \& Mellahi, 2016).

To summarize, our analysis has responded to regular calls for the conduct of a structured and systematic review in an under researched region of the world. This has helped to map the developments in HRM along the macro level economic, political and other institutional changes taking place in the Middle East. Also, the comprehensive review analysis has helped us to confidently propose agenda for future research investigations, research along which will make useful contributions and help the field of HRM develop further in the region. In order to conduct robust research analyses, it will be critical to utilize contextrelevant measures and robust methodologies. We would, accordingly, urge researchers to move away from conducting investigations that have been shown to have severe limitations, as well as weaknesses in methodologies (e.g., blindly adopting constructs and measures developed in the West or adopting cross-sectional analysis). Irrespective of whether HRM in the Middle East converges or diverges in due course, will depend on the dominance of the forces contributing to either.

Acknowledgments We would like to thank both the reviewer and Professor C.-S. Wong for their constructive comments on an earlier version of this manuscript. They guided us to significantly improve the quality of our paper.

Open Access This article is distributed under the terms of the Creative Commons Attribution 4.0 International License (http://creativecommons.org/licenses/by/4.0/), which permits unrestricted use, distribution, and reproduction in any medium, provided you give appropriate credit to the original author(s) and the source, provide a link to the Creative Commons license, and indicate if changes were made. 


\section{References}

Abalkhail, J. M. 2017. Women and leadership: Challenges and opportunities in Saudi higher education. Career Development International, 22(2): 165-183.

Abdalla, I. A. 2015. Career facilitators and barriers of Arab women senior executives. International Journal of Business and Management, 10(8): 218-232.

Abdelkarim, A. 2001. UAE labour market and problems of employment of nationals, an overview and policy agenda. Research report no. 1, Centre for Labour Market Research and Information, Tanmia, Dubai.

Afiouni, F., Karam, C. M., \& El-Hajj, H. 2013. The HR value proposition model in the Arab Middle East: Identifying the contours of an Arab Middle Eastern HR model. International Journal of Human Resource Management, 24(10): 1895-1932.

Afiouni, F., Ruël, H., \& Schuler, R. 2014. HRM in the Middle East: Toward a greater understanding. International Journal of Human Resource Management, 25(2): 133-143.

Ahmad, M. 2004. When does final means final?. Arab News: November, 4.

Aladwan, K., Bhanugopan, R., \& D’Netto, B. 2015. The effects of human resource management practices on employees' organisational commitment. International Journal of Organizational Analysis, 23(3): 472492.

Al-Ajmi, K., Hirekhan, M., Budhwar, P., \& Singh, S. 2016. Employment relations of domestic workers in Kuwait: The employer's perspective. In P. Budhwar, \& K. Mellahi (Eds.). Handbook of human resource management in the Middle East: 263-283. Cheltenham: Edward Elgar.

Al Ali, A. A., Singh, S. K., Al Nahyan, M., \& Sohal, A. S. 2017. Change management through leadership: The mediating role of organizational culture. International Journal of Organizational Analysis, 25(4): 723-739.

Al-Asfour, A., Tlaiss, H. A., Khan, S. A., \& Rajasekar, J. 2017. Saudi women's work challenges and barriers to career advancement. Career Development International, 22(2): 184-199.

Aldossari, M., \& Robertson, M. 2015. The role of wasta in repatriates' perceptions of a breach to the psychological contract: A Saudi Arabian case study. International Journal of Human Resource Management: 1-20.

Al-Enzi, A. 2002. Kuwait's employment policy: Its formulation, implications, and challenges. International Journal of Public Administration, 25(7): 885-900.

Al-Hamadi, A. B., Budhwar, P., \& Shipton, H. 2007. Managing human resources in the Sultanate of Oman. International Journal of Human Resource Management, 18(1): 100-113.

Al-Husan, F. B., \& AlHussan, F. B. 2016. Privatization, investments and HR in foreign firms operating in the Middle East. In P. Budhwar, \& K. Mellahi (Eds.). Handbook of human resource management in the Middle East: 339-366. Cheltenham: Edward Elgar.

Ali, A. 2004. Islamic perspectives on management and organization. Cheltenham: Edward Elgar.

Ali, A. 2010. Islamic challenges to HR in modern organizations. Personnel Review, 39(6): 692-711.

Ali, A. 2011. Talent management in the Middle East. Global Talent Management: 155-178.

Ali, A., \& Al-Kazemi, A. 2006. Human resource management in Kuwait. In P. Budhwar, \& K. Mellahi (Eds.). Managing human resources in the Middle East: 79-96. London: Routledge.

Ali, F., Malik, A., Pereira, V., \& Al Ariss, A. 2016. A relational understanding of work-life balance of Muslim migrant women in the West: Future research agenda. International Journal of Human Resource Management, 8(SI): 1163-1181.

Al-Jahwari, M., \& Budhwar, P. 2016. Human resource management in Oman. In P. Budhwar, \& K. Mellahi (Eds.). Handbook of human resource management in the Middle East: 87-122. Cheltenham: Edward Elgar.

AlMazrouei, H., \& Pech, R. J. 2015. Working in the UAE: Expatriate management experiences. Journal of Islamic Accounting and Business Research, 6(1): 73-93.

Al-Nasser, A., \& Behery, M. 2015. Examining the relationship between organizational coaching and workplace counterproductive behaviours in the United Arab Emirates. International Journal of Organizational Analysis, 23(3): 378-403.

Al-Rasheed, A. M. 2001. Features of traditional Arab management and organization in the Jordan business environment. Journal of Transnational Management Development, 6(1-2): 27-53.

Altarawneh, I., \& Aldehayyat, J. S. 2011. Strategic human resources management (SHRM) in Jordanian hotels. International Journal of Business and Management, 6(10): 242-255.

Al-Waqfi, M. A., \& Forstenlechner, I. 2014. Barriers to Emiratization: The role of policy design and institutional environment in determining the effectiveness of Emiratization. International Journal of Human Resource Management, 25(2): 167-189. 
Ancarani, A., Ayach, A., Di Mauro, C., Gitto, S., \& Mancusco, P. 2016. Does religious diversity in health team composition affect efficiency? Evidence from Dubai. British Journal of Management, 27(4): 740-759.

Anwar, S. A. 2003. Globalisation of corporate America and its implications for management styles in an Arabian cultural context. International Journal of Management, 20(1): 43-52.

Aycan, Z. 2001. Human resource management in Turkey - Current issues and future challenges. International Journal of Manpower, 22(3): 252-263.

Aycan, Z. 2004. Key success factors for women in management in Turkey. Applied Psychology, 53(3): 453471.

Aycan, Z. 2006. Human resource management in Turkey. In P. Budhwar, \& K. Mellahi (Eds.). Managing human resources in the Middle East: 160-179. London: Routledge.

Aycan, Z., Al-Hamadi, A. B., Davis, A., \& Budhwar, P. 2007. Cultural orientations and preference for HRM policies and practices: The case of Oman. International Journal of Human Resource Management, 18(1): 11-32.

Badawy, M. K. 1980. Styles of middle eastern managers. California Management Review, 22(2): 51-58.

Benson, P., \& Al Arkoubi, K. 2006. Human resource management in Morocco. In P. Budhwar, \& K. Mellahi (Eds.). Managing human resources in the Middle East: 273-290. London: Routledge.

Biygautane, M., \& Al Yahya, K. O. 2014. Talent management in the MENA and GCC regions: Challenges and opportunities. In A. Al Ariss (Ed.). Global talent management: Challenges, strategies, and opportunities: 197-215. Cham: Springer International.

Bozionelos, N., \& Singh, S. K. 2017. The relationship of emotional intelligence with task and contextual performance: More than it meets the linear eye. Personality and Individual Differences, 116(1): 206-211.

Branine, M. 2004. Human resource management in Algeria. In P. Budhwar, \& Y. Debrah (Eds.). HRM in developing countries: 155-173. London: Routledge.

Branine, M. 2006. Human resource management in Algeria. In P. Budhwar, \& K. Mellahi (Eds.). Managing human resources in the Middle East: 250-272. London: Routledge.

Branine, M., \& Pollard, D. 2010. Human resource management with Islamic management principles: A dialectic for a reverse diffusion in management. Personnel Review, 39(6): 712-727.

Brewster, C., Mayrhofer, W., \& Cooke, F. L. 2015. Convergence, divergence and diffusion of HRM in emerging markets. In F. Horwitz, \& P. Budhwar (Eds.). Handbook of human resource management in emerging markets: 451-469. Cheltenham: Edward-Elgar.

Budhwar, P., \& Debrah, Y. A. 2009. Future research on human resource management systems in Asia. Asia Pacific Journal of Management, 26(2): 197-218.

Budhwar, P., \& Mellahi, K. 2006. Introduction: Managing human resources in the Middle East. In P. Budhwar, \& K. Mellahi (Eds.). Managing human resources in the Middle East: 1-19. London: Routledge.

Budhwar, P., \& Mellahi, K. 2010. Introduction: Islam and human resource management. Personnel Review, 39(6): 685-691.

Budhwar, P., \& Mellahi, K. 2016. (Eds.). Handbook of human resource management in the Middle East. Cheltenham: Edward Elgar.

Budhwar, P., Varma, A., \& Patel, C. 2016. Convergence-divergence of HRM in Asia: Context-specific analysis and future research agenda. Human Resource Management Review, 26(December): 311-326.

Chapman, D. W., \& Miric, S. L. 2009. Education quality in the Middle East. International Review of Education, 55(4): 311-344.

Chen, S.-Y., Chuang, S.-H., \& Chen, S.-j. 2018. A conceptual review of human resource management research and practice in Taiwan with comparison to select economies in East Asia. Asia Pacific Journal of Management, 35(1): 213-239.

Chow, I. H.-s., Teo, S. T. T., \& Chew, I. K.-H. 2013. HRM systems and firm performance: The mediation role of strategic orientation. Asia Pacific Journal of Management., 30(1): 53-72.

Cooke, F. L. 2018. Concepts, contexts, and mindsets: Putting human resource management research in perspectives. Human Resource Management Journal, 28(1): 1-13.

Cunningham, R. B., \& Sarayrah, Y. K. 1993. Wasta: The hidden force in middle eastern society. Westport: Praeger.

Deloitte. 2015. Deloitte: Middle East organizations facing human capital trends and challenges. http://www. bq-magazine.com/economy/employment-economy/2015/06/hr-challenges-in-the-middle-east, Accessed October 10, 2015.

Darwish, T. K., Singh, S., \& Wood, G. 2016. The impact of human resource practices on actual and perceived organizational performance in Middle Eastern emerging market. Human Resource Management, 55(2): 261-281.

de Waal, A., \& Sultan, S. 2012. Applicability of the high performance organization framework in the Middle East. Education, Business and Society: Contemporary Middle Eastern Issues, 5(3): 213-223. 
DiMaggio, P., \& Powell, W. W. 1983. The iron cage revisited: Collective rationality and institutional isomorphism in organizational fields. American Sociological Review, 48(2): 147-160.

Dirani, K. M., \& Hamie, C. S. 2017. Human resource education in the Middle East region. European Journal of Training \& Development, 41(2): 102-118.

Dowling, P., Festing, M., \& Engles, A. 2013. International human resource management. London: Thomson.

Elamin, A. M., \& Tlaiss, H. A. 2015. Exploring the relationship between organizational citizenship behavior and organizational justice in the Islamic Saudi Arabian context. Employee Relations, 37(1): 2-29.

Elmuti, D., \& Kathawala, Y. 1991. An investigation of the human resources management practices of Japanese subsidiaries in the Arabian gulf region. Journal of Applied Business Research, 7(2): 82-89.

Enshassi, A., \& Burgess, R. 1991. Managerial effectiveness and the style of management in the Middle East: An empirical analysis. Construction Management and Economics, 9(1): 79-93.

Farouk, S., Abu Elanain, H. M., Obeidat, S. M., \& Al Nahyan, M. 2016. HRM practices and organizational performance in the UAE banking sector. International Journal of Productivity and Performance Management, 65(4): 773-791.

Fiegenbaum, A., \& Lavie, D. 2000. Strategic management of MNCs' entry into foreign markets: Experience of Israel in the 1990s. European Management Journal, 18(1): 93-102.

Forstenlechner, I. 2010. Expats and citizens: Managing diverse teams in the Middle East. Team Performance Management, 16(5/6): 237-241.

Forstenlechner, I., \& Mellahi, K. 2011. Gaining legitimacy through hiring local workforce at a premium: The case of MNEs in the United Arab Emirates. Journal of World Business, 46(4): 455-461.

Gao, C., Zuzul, T., Jones, G., \& Khanna, T. 2017. Overcoming institutional voids: A reputation-based view of long-run survival. Strategic Management Journal, 38(11): 2147-2167.

Gerrard, B., \& Lockett, A. 2018. Team-specific human capital and performance. British Journal of Management, 29(1): 10-25.

Goby, V. P., Nickerson, C., \& David, E. 2015. Interpersonal communication and diversity climate: Promoting workforce localization in the UAE. International Journal of Organizational Analysis, 23(3): 364-377.

Greenwood, R., \& Hinings, C. R. 1996. Understanding radical organizational change: Bringing together the old and the new institutionalism. Academy of Management Review, 21(4): 1022-1054.

Guardian. 2015. Indonesia to stop sending domestic workers to Middle East-Reports. http://www. theguardian.com/world/2015/may/05/indonesia-to-stop-sending-domestic-workers-to-middle-eastreports, Accessed September 1, 2015.

Harrison, E. C., \& Haslberger, A. 2016. Expatriate management across the Middle East and North Africa region. In P. Budhwar, \& K. Mellahi (Eds.). Handbook of human resource management in the Middle East: 309-326. Cheltenham: Edward Elgar.

Harrison, E. C., \& Michailova, S. 2012. Working in the Middle East: Western female expatriates' experiences in the United Arab Emirates. International Journal of Human Resource Management, 23(4): 625-644.

Harry, W. 2007. Employment creation and localization: The crucial human resource issues for the GCC. International Journal of Human Resource Management, 18(1): 132-146.

Harry, W. 2016. Society-level factors impacting human resource management in the Middle East. In P. Budhwar, \& K. Mellahi (Eds.). Handbook of human resource management in the Middle East: 35-48. Cheltenham: Edward Elgar.

Hatem, T. 2006. Human resource management in Egypt. In P. Budhwar, \& K. Mellahi (Eds.). Managing human resources in the Middle East: 199-218. London: Routledge.

Hayfaa, A. T., \& Dirani, K. M. 2015. Women and training: An empirical investigation in the Arab Middle East. Human Resource Development International, 18(4): 366-386.

Horwitz, F. M., \& Budhwar, P. (Eds.). 2015. Handbook of human resource management in emerging markets. Cheltenham and Northampton: Edward Elgar.

Howe-Walsh, L., Turnbull, S., \& Boulanouar, A. 2015. International human resource management: Implications for multinational corporations operating in the Arab Middle East. International Journal of Human Resources Development \& Management, 15(2/3/4): 258-274.

Iles, P., Almhedie, A., \& Baruch, Y. 2012. Managing HR in the Middle East: Challenges in the public sector. Public Personnel Management, 41(3): 465-492.

Izraeli, D. N. 1987. Women's movement into management in Israel. International Studies of Management and Organization, 16(3-4): 76-108.

Jabeen, F., Behery, M., \& Hossam Abu Elanain, H. 2015. Examining the relationship between the psychological contract and organisational commitment: The mediating effect of transactional leadership in the UAE context. International Journal of Organizational Analysis, 23(1): 102-122. 
Jackson, S. E., \& Schuler, R. S. 1999. Understanding human resource management in the context of organizations and their environments. In R. Schuler, \& S. E. Jackson (Eds.). Strategic human resource management: A reader: 4-28. London: Blackwell.

Jackson, S. E., Schuler, R. S., \& Jiang, K. 2014. An aspirational framework for strategic human resource management. Academy of Management Annals, 8: 1-56.

Kabasakal, H., \& Bodur, M. 2002. Arabic cluster: A bridge between east and west. Journal of World Business, 37(1): 40-54.

Katou, A., Budhwar, P., Woldu, H., \& Al-Hamadi, A. B. 2010. Influence of ethical beliefs, national culture and institutions on preferences for HRM in Oman. Personnel Review, 39(6): 728-745.

Kaya, N. 2006. The impact of HRM practices and corporate entrepreneurship on firm performance: Evidence from Turkish firms. International Journal of Human Resource Management, 17(12): 2074-2092.

Khan, S. A. 2011. Convergence, divergence or middle of the path: HRM model for Oman. Journal of Management Policy and Practice, 12(1): 76-87.

Khan, S. A., Rajasekar, J., \& Al-Asfour, A. 2015. Organizational career development practices: Learning from an Oman company. International Journal of Business and Management, 10(9): 88-98.

Kim, H., \& Sung-Choon, K. 2013. Strategic HR functions and firm performance: The moderating effects of high-involvement work practices. Asia Pacific Journal of Management, 30(1): 91-113.

Klien, H. J., \& Delery, J. E. 2012. Construct clarity in human resource management research: Introduction to the Special Issue. Human Resource Management Review, 22(2): 55-61.

Kolachi, N., \& Akan, O. 2014. HRD role in organizational development (a case of corporate thinking at ETISALT, UAE). International Business Research, 7(8): 160-167.

Leat, M., \& El-Kot, G. 2007 HRM practices in Egypt: The influence of national context?. International Journal of Human Resource Management, 18(1): 147-158.

Leung, K. 2012. Indigenous Chinese management research: Like it or not, we need it. Management and Organization Review, 8(1): 1-5.

Lofters, A., Slater, M., Fumakia, N., \& Thulien, N. 2014. "Brain drain" and "brain waste": Experiences of international medical graduates in Ontario. Risk Management and Healthcare Policy, 7: 81-89.

Ma, Z., Long, L., Zhang, Y., Zhang, J., \& Lam, C. K. 2017. Why do high-performance human resource practices matter for team creativity? The mediating role of collective efficacy and knowledge sharing. Asia Pacific Journal of Management, 34(3): 565-586.

Maamari, B. E., \& Majdalani, J. F. 2017. Emotional intelligence, leadership style and organizational climate. International Journal of Organizational Analysis, 25(2): 327-345.

Manafi, M., \& Subramaniam, I. D. 2015. Relationship between human resources management practices, transformational leadership and knowledge sharing on innovation in Iranian electronic industry. Asian Social Science, 11(10): 358-385.

Manseau, G. S. 2007. Contractual solutions for migrant labourers: The case of domestic workers in the Middle East. Human Rights Law Commentary, 3: 25-47.

Marmenout, K., \& Lirio, P. 2014. Local female talent retention in the Gulf: Emirati women bending with the wind. International Journal of Human Resource Management, 25(2): 144-166.

Marriot, R. G. 1986. Ads require sensitivity to Arab culture, religion. Marketing News, 20(9): 3-5.

Matherly, L., \& Al Nahyan, S. S. 2015. Workplace quotas: Building competitiveness through effective governance of national-expatriate knowledge transfer and development of sustainable human capital. International Journal of Organizational Analysis, 23(3): 456-471.

Mellahi, K. 2003. National culture and management practices: The case of GCCs. In M. Tayeb (Ed.). International management: Theory and practices: 87-105. London: Prentice Hall.

Mellahi, K. 2006. Human resource management in Saudi Arabia. In P. Budhwar, \& K. Mellahi (Eds.). Managing human resources in the Middle East: 97-120. London: Routledge.

Mellahi, K. 2007. The effect of regulations on HRM: Private sector firms in Saudi Arabia. International Journal of Human Resource Management, 18(1): 85-99.

Mellahi, K., \& Budhwar, P. 2006. HRM challenges in the Middle East: Agenda for future research and policy. In P. Budhwar, \& K. Mellahi (Eds.). Managing human resources in the Middle East: 291-301. London: Routledge.

Mellahi, K., Demirbag, M., Collings, D. G., Tatoglu, E., \& Hughes, M. 2013. Similarly different: A comparison of HRM practices in MNE subsidiaries and local firms in Turkey. International Journal of Human Resource Management, 24(12): 2339-2368.

Mellahi, K., \& Wood, G. 2004. Human resource management in Saudi Arabia. In P. Budhwar, \& Y. Debrah (Eds.). HRM in developing countries: 135-151. London: Routledge.

Metcalfe, B. D. 2008. Women, management and globalization in the Middle East. Journal of Business Ethics, 83(1): $85-100$. 
Metle, M. K. 2002. The influence of traditional culture on attitudes towards work among Kuwati women employees in the public sector. Women in Management Review, 17(5-6): 245-262.

Meyer, K. E. 2006. Asian management research needs more self-confidence. Asia Pacific Journal of Management, 23(2): 119-137.

Mohamed, M. I., Multalib, M. A., Abdulaziz, A. M., Ibrahim, M., \& Habtoor, N. A. S. 2015. A review of HRM practices and labor productivity: Evidence from Libyan oil companies. Asian Social Science, 11(9): 215-225.

Mohammad, A. A. \& Hamdy, H. 2008. The stigma of wasta: The effect of wasta on perceived competence and morality. Working paper series no. 5, German University in Cairo, New Cairo City.

Moideenkutty, U., Al-Lamki, A., \& Sree Rama Murthy, Y. 2011. HRM practices and organizational performance in Oman. Personnel Review, 40(2): 239-251.

Mostafa, A. M. S., \& Gould-Williams, J. S. 2014. Testing the mediation effect of person-organization fit on the relationship between high performance HR practices and employee outcomes in the Egyptian public sector. International Journal of Human Resource Management, 25(2): 276-292.

Nakhle, S. 2011. The transfer of human resource practices from American and European multinational companies to their Lebanese subsidiaries: A study of the host-country effects and of the standardizationadaptation dilemma. Fribourg: University of Fribourg.

Namazie, P., \& Frame, P. 2007. Development in human resource management in Iran. International Journal of Human Resource Management, 18(1): 159-171.

Namazie, P., \& Pahlavnejad, A. M. 2016. Human resource management in Iran. In P. Budhwar, \& K. Mellahi (Eds.). Handbook of human resource management in the Middle East: 161-179. Cheltenham: Edward Elgar.

Namazie, P., \& Tayeb, M. 2006. Human resource management in Iran. In P. S. Budhwar, \& K. Mellahi (Eds.). Managing human resources in the Middle East: 20-39. London: Routledge.

Namazie, P., \& Venegas, B. C. 2016. Cultural perspectives in human resource management in the Middle East and North Africa. In P. Budhwar, \& K. Mellahi (Eds.). Handbook of human resource management in the Middle East: 15-34. Cheltenham: Edward Elgar.

Nguyen, D. T. N., Teo, S. T. T., \& Ho, M. 2018. Development of human resource management in Vietnam: A semantic analysis. Asia Pacific Journal of Management, 35(1): 241-284.

Obeidat, B. Y., Masa'deh, R., Moh'd, T., \& Abdallah, A. B. 2014. The relationships among human resource management practices, organizational commitment, and knowledge management processes: A structural equation modeling approach. Journal of Business and Management, 9(3): 9-26.

Obeidat, S. M. 2017. An examination of the moderating effect of electronic-HRM on high-performance work practices and organisational performance link. Evidence-based HRM, 5(2): 222-241.

Obeidat, S. M., Mitchell, R., \& Bray, M. 2016. The link between high performance work practices and organizational performance: Empirically validating the conceptualization of HPWP according to the AMO model. Employee Relations, 38(4): 578-595.

Omair, K. 2010. Typology of career development for Arab women managers in the United Arab Emirates. Career Development International, 15(2): 121-143.

Özden, C. 2006. Brain drain in Middle East and North Africa-The patterns under the surface. Report by United Nations expert group meeting on international migration and development in the Arab region. UN/ POP/EGM/2006/10, Population Division, Department of Economic and Social Affairs United Nations Secretariat, Beirut, May 15-17.

Pande, A. 2013. The paper that you have in your hand is my freedom: Migrant domestic work and the sponsorship (kafala) system in Lebanon. International Migration Review, 47(2): 414-441.

Powell, W. W., \& DiMaggio, P. J. (Eds.) 2012. The new institutionalism in organizational analysis. Chicago: University of Chicago Press.

Raheem, S. 2016. Talent management in the Middle East. In P. Budhwar, \& K. Mellahi (Eds.). Handbook of human resource management in the Middle East: 63-82. Cheltenham: Edward Elgar.

Ramdani, B., Mellahi, K., Guermat, C., \& Kechad, R. 2014. The efficacy of high performance work practices in the Middle East: Evidence from Algerian firms. International Journal of Human Resource Management, 25(2): 252-275.

Rees, C. J., Mamman, A., \& Braik, A. B. 2007. Emiratization as a strategic HRM change initiative: Case study evidence from a UAE petroleum company. International Journal of Human Resource Management, 18(1): 33-53.

Rodriquez, J. K., \& Scurry, T. 2014. Career capital development of self-initiated expatriates in Qatar: Cosmopolitan globetrotters, experts and outsiders. International Journal of Human Resource Management, 25(2): 190-211. 
Ryan, J. C. 2016. Old knowledge for new impacts: Equity theory and workforce nationalization. Journal of Business Research, 69(5): 1587-1592.

Saini, D., \& Budhwar, P. 2008. Managing the human resource in Indian SMEs: The role of indigenous realities in organizational working. Journal of World Business, 43(4): 417-434.

Saleh, S., \& Kleiner, B. H. 2005. Issues and concerns facing American companies in the Middle East. Management Research News, 28(2/3): 56-62.

Scott, R. 2004. Institutions and organizations: Foundations for organizational science. London: Sage.

Scott, W. R. (Ed.) 2008. Institutions and organizations-Ideas and interests. Los Angeles: Sage.

Scott-Jackson, W., Porteous, A., Gurel, O., \& Rushent, C. 2014. Building GCC national talent for strategic competitive advantage. Oxford: Oxford Strategic Consulting Research Series.

Sidani, Y., \& Al Ariss, A. 2014. Institutional and corporate drivers of global talent management: Evidence from the Arab gulf region. Journal of World Business, 49(2): 215-224.

Sidani, Y. M., Konard, A., \& Karam, C. M. 2015. From female leadership advantage to female leadership deficit: A developing country perspective. Career Development International, 20(3): 273-292.

Silbiger, A., Berger, R., Barnes, B. R., \& Renwick, D. W. S 2017. Improving expatriation success: The roles of regulatory focus and burnout. British Journal of Management, 28(2): 231-247.

Singh, A., \& Sharma, J. 2015. Strategies for talent management: A study of select organizations in the UAE. International Journal of Organizational Analysis, 23(3): 337-347.

Smith, P. B., Torres, C., Leong, C.-H., Budhwar, P., Achoui, M., \& Lebedeva, N. 2012. Are indigenous approaches to achieving influence in business organizations distinctive? A comparative study of guanxi, wasta, jeitinho, svyazi, and pulling strings. International Journal of Human Resource Management, 23(2): 333-348.

Soltani, E., \& Liao, Y.-Y. 2010. Training interventions: Fulfilling managerial ends or proliferating invaluable means for employees?: Some evidence from Iran. European Business Review, 22(2): 128-152.

Spyridonidis, D., \& Currie, G. 2016. The translational role of hybrid nurse middle managers in implementing clinical guidelines: Effect of, and upon, professional and managerial hierarchies. British Journal of Management, 27(4): 760-777.

Srour, F. J., Srour, I., \& Lattouf, M. G. 2017. A survey of absenteeism on construction sites. International Journal of Manpower, 38(4): 533-547.

Su, Z., Guo, H., \& Sun, W. 2017. Exploration and firm performance: The moderating impact of competitive strategy. British Journal of Management, 28(3): 357-371.

Sumbal, M. S., Tsui, E., See-to, E., \& Barendrecht, A. 2017. Knowledge retention and aging workforce in the oil and gas industry: A multi perspective study. Journal of Knowledge Management, 21(4): 907-924.

Syed, J., Hazboun, N. G., \& Murray, P. A. 2014. What locals want: Jordanian employees' views on expatriate managers. International Journal of Human Resource Management, 25(2): 212-233.

Ta'Amnha, M., Sayce, S., \& Tregaskis, O. 2016. Wasta in the Jordanian context. In P. Budhwar, \& K. Mellahi (Eds.). Handbook of human resource management in the Middle East: 393-411. Cheltenham: Edward Elgar.

Thite, M., Wilkinson, A., \& Shah, D. 2012. Internationalization and HRM strategies across subsidiaries in multinational corporations from emerging economies-A conceptual framework. Journal of World Business, 47(2): 251-258.

Tlaiss, H. 2015. Neither-nor: Career success of women in an Arab Middle Eastern context. Employee Relations, 37(5): 525-546.

Tranfield, D., Denyer, D., \& Smart, P. 2003. Towards a methodology for developing evidence-informed management knowledge by means of systematic review. British Journal of Management, 14(3): 207-222.

Tzafair, S. S., Meshoulam, I., \& Baruch, Y. 2007. HRM in Israel: New challenges. International Journal of Human Resource Management, 18(1): 114-131.

Varma, A., Aycan, Z., Budhwar, P., Pichler, S., Uygur, U., \& Paluch, R. 2016. Host country nationals' support to expatriates: An investigation in Turkey. European Journal of International Management, 10(6): 605-623.

Waxin, M. F., \& Bateman, R. 2016. Labour localisation and HRM practices in the Gulf countries. In P. Budhwar, \& K. Mellahi (Eds.). Handbook of human resource management in the Middle East: 284-308. Cheltenham: Edward Elgar.

Yaghi, A. 2016. Is it the human resource policy to blame?: Examining intention to quit among women managers in Arab Middle Eastern context. Gender in Management: An International Journal, 31(7): 479495.

Yahiaoui, D. 2007. L'hybridation des pratiques de GRH dans les filiales Françaises implantées en Tunisie. Reproduction de: Thèse de doctorat, Universite Jean Moulin Lyon 3, Lyon.

Zaitouni, M., Sawalha, N. N., \& Al Sharif, A. 2011. The impact of human resource management practices on organizational commitment in the banking sector in Kuwait. International Journal of Business and Management, 6(6): 108-123. 
Pawan Budhwar (PhD, Manchester Business School) is Professor of International Human Resource Management (HRM), an Associate Pro Vice Chancellor International (India) and the Director of Aston India Centre for Applied Research, Aston University, Birmingham, UK. Pawan is the Co-Editor-in-Chief of British Journal of Management and Associate Editor of Human Resource Management. He is the co-founder and first President of the Indian Academy of Management, an affiliate of the AOM. Pawan's research interest is in the broad area of HRM in emerging markets with a specific focus on India. He has published over 110 articles in leading journals and has also written and/or co-edited 18 books. Pawan is a Fellow of the Higher Education Academy, British Academy of Management, the Academy of Social Sciences and the Indian Academy of Management. He was AOM Caucuses Chair in 2009. He has been regularly invited to deliver keynote speeches at major conferences and has won many research related awards.

Vijay Pereira ( $\mathrm{PhD}$, University of Portsmouth) is Associate (Dean of Research and Professor of Strategic and International HRM) at the University of Wollongong in Dubai, UAE. He is also the Associate Editor (Strategic Management and Organization Behavior), Journal of Business Research. Dr. Pereira is an adjunct at Portsmouth University, UK and a visiting scholar at Manchester University, UK. Dr. Pereira has a track record of attracting funding and has published widely, in over 100 outlets, including in leading international journals such as the HRM US, Journal of World Business, International Journal of HRM, Journal of Business Research, Journal of International Management, and International Journal of Production Research, among others. He is currently on the editorial and advisory board for the journals Production and Operations Management (Listed in Financial Times), Asia Pacific Journal of Management, Asian Business \& Management Journal and South Asian History and Culture.

Kamel Mellahi (PhD, University of Nottingham) is Professor of Strategic Management at Warwick Business School, UK. He obtained his PhD from the University of Nottingham, coming to WBS from a Chair in Strategic Management at The University of Sheffield Management School, where he was Head of the Management Division. Professor Mellahi's research focuses on organizational failure and renewal, business ethics and sustainability, and international business strategy with particular emphasis on emerging economies. He has published three books and over 80 papers in top strategy and international business journals such as the Strategic Management Journal, Journal of International Business Studies, and Journal of Management Studies. He serves on the editorial board on several leading journals such as the International Journal of Management Reviews, Journal of World Business, and British Journal of Management, among others. He has delivered executive courses and provided policy advice to numerous public and private organizations.

Sanjay Kumar Singh (PhD, University of Delhi) is Associate Professor of Management at the College of Business Administration, Abu Dhabi University, Abu Dhabi, UAE. He has published over 40 refereed journal articles and five books. He has been Editor of Special Issue(s) in several refereed journals such as the International Journal of Organizational Analysis, International Journal of Productivity and Performance Management, Journal of Enterprise Information Management, Journal of Workplace Learning, International Journal of Work Organisation and Emotion, Management Decision, International Journal of Educational Management, Gender in Management: An International Journal, Benchmarking: An International Journal, and Journal of Organizational Change Management, to name a few. He is on the Editorial Advisory Board of the International Journal of Organisational Analysis, International Journal of Productivity and Performance Management, and International Journal of Value Chain Management. 